\title{
Erratum to: Computer Simulation Within Action Research: A Promising Combination for Improving Healthcare Delivery?
}

\author{
R. W. Rosmulder · J. J. Krabbendam - A. H. M. Kerkhoff • \\ C. M. Houser • J. S. K. Luitse
}

Published online: 12 April 2011

(C) The Author(s) 2011

\section{Erratum to: Syst Pract Action Res DOI 10.1007/s11213-011-9191-y}

The following Acknowledgment (missing from the article as published) should be noted:

We also wish to thank Paul Coughlan and David Coghlan for providing helpful comments on earlier versions of the manuscript.

The online version of the original article can be found under doi:10.1007/s11213-011-9191-y.

R. W. Rosmulder $(\bowtie) \cdot$ J. J. Krabbendam

Department of Operations, Organization and Human Resources,

University of Twente, P.O. Box 217, 7500 AE Enschede, The Netherlands

e-mail: r.w.rosmulder@utwente.nl

\section{A. H. M. Kerkhoff}

University of Twente, Enschede, The Netherlands

C. M. Houser · J. S. K. Luitse

Emergency Department, Academic Medical Centre,

University of Amsterdam, Amsterdam, The Netherlands 